\title{
Yhteistoiminnallisen oppimisen ylistys
}

Saloviita, Timo (2006). Yhteistoiminnallinen oppiminen ja osallistava kasvatus. PS-Kustannus. $200 \mathrm{~s}$.

Opetusmenetelmiä käsittelevälle kirjallisuudelle on kysyntää. Kouluttajan uraansa aloittelevat kaipaavat niitä kehityksensä ohjenuoriksi, pidemmälle ehtineet voivat käyttää niitä työnsä tukena. Menetelmäkirjallisuus on parhaimmillaan selkeästi kirjoitettua, käytäntöön suuntautunutta sekä alan tutkimukseen kytkettyä. Timo Saloviidan teos vastaa tähän tarpeeseen: se on yleistajuisesti kirjoitettu, mutta tieteellisesti argumentoitu katsaus menetelmään, jolla on paikkansa myös aikuiskouluttajan työkalupakissa.

Kirja on pyritty kirjoittamaan käytännönläheisesti. Kirjassa on monia arkisia esimerkkejä, jotka kaikki sijoittuvat peruskouluun. Ratkaisu tuo mukanaan tiettyjä ennakko-olettamuksia. Kirjan lukijakunnan oletetaan koostuvan opettajista, jotka opettavat samanikäisiä henkilöitä. Ryhmäkoko vastaa peruskoulun ryhmäkokoa. Opetus kestää 45 minuuttia. Ryhmä koostuu lapsista. Ryhmän kanssa toimitaan lukuvuoden mittaisen ajan verran. Opetus tapahtuu luokkahuoneessa eikä esimerkiksi verkon oppimisalustalla.

Nämä peruskoulun rakenteelliset reunaehdot poikkeavat merkittävästi vaikkapa vapaan sivistystyön toiminnasta, mikä laskee kirjan käytettävyyttä aikuiskoulutuksessa. Esimerkiksi lukupiirin kaltainen perinteinen yhteistoiminnallinen ja vapaaehtoinen oppimismuoto jää huomiotta. Kirjasta lieneekin suurinta iloa peruskoulun opet- tajille, heistäkin ehkä eniten luokanopettajille. Teos tarjoaa toki välineitä analysoida omaa toimintaa kouluttajana myös aikuisten parissa.

\section{Oppiminen ryhmäilmiönä}

Kirja jakautuu neljänä osaan. Ensimmäinen osio tarkastelee yhteistoiminnallista oppimista sosiaalipsykologiseen tietoon tukeutuen. Toinen esittelee erilaisia yhteistoiminnallisia menetelmiä. Kolmas käsittelee tutkimustuloksia siitä, miten menetelmien käyttö on näkynyt oppimistuloksissa. Neljäs osio vetää tekstiä yhteen kysymyksin ja vastauksin. Kiireinen lukija hyötyy eniten viimeisen osion lukemista, josta selviävät Saloviidan näkemykset menetelmästä sekä sen soveltamisesta.

Saloviita on omaksunut maltillisen lähestymistavan. Hän ei pyri argumentoimaan, että kouluissa tulisi siirtyä yksinomaan yhteistoiminnalliseen oppimiseen. Hän tarjoaa sitä työtavaksi opettajajohtoisempien menetelmien lisäksi. Hän pyrkii vakuuttamaan lukijansa osoittamalla, että yhteistoiminnallinen oppiminen lisää aikaa, jonka yksittäinen oppilas on äänessä, opettaa ryhmässä toimimisen taitoja sekä luo parempia oppimistuloksia.

Oppimista tarkastellaan kirjassa sosiaalisena prosessina. Tärkeän tietoperustan muodostavat sosiaalipsykologiset teoriat ryhmän vaikutuksesta yksilön suoritukseen, ryhmän kehitys- vaiheista sekä ryhmän rooleista. Saloviita on tietoinen - kuten yhteistoiminnallisen oppimisen edustajat ylipäätään - siitä, että ryhmätyöskentely sinänsä ei automaattisesti tuota hyviä oppimistuloksia. Saloviita nostaa esiin neljä vaatimusta, joita menestyksellinen ryhmätyö edellyttää. Osallistujilla on oltava suoraa vuorovaikutusta keskenään. Ryhmän jäsenten välillä on oltava positiivista keskinäisriippuvuutta. Tällä tarkoitetaan, että ryhmän toiminta tulee rakentaa sellaiseksi, että yksilöiden suoritukset hyödyttävät koko ryhmän tulosta. Yksilöillä on oltava vastuuta, jotta vapaamatkustajan ongelmaa ei pääse syntymään. Ryhmätyöt rakennetaan siten, että ne edellyttävät yhtäläistä osallistumista. Kysymys, miten ryhmä ryhmäytetään toimivaksi, jää teoksessa vähälle huomiolle.

Yhteistoiminnallisina työtapoina Saloviita esittelee tarkemmin Kaganin rakenteellisen mallin, Aronsonin palapelitekniikan sekä Cohenin kompleksiopetuksen. Muita malleja käsitellään lyhyemmin.

\section{Erilaisuuden \\ huomioiminen}

Suomeksi on jo aiemmin ollut luettavissa teoksia yhteistoiminnallisesta oppimisesta sekä sen soveltamisesta suomalaisessa koulukontekstissa. Ilmeinen vertailukohta on Pasi Sahlbergin ja Slomo Sharanin toimittama Yhteistoiminnallisen oppimisen käsikirja (WSOY 2001). Saloviidan teos ei edusta samaa teoreettista tasoa eikä sivumääräisesti 
suppeampana kirjana saavuta samaa tarkastelun laajuutta. Lisäksi monet Saloviidan esittelemät tekniikat on esitelty tässä teoksessa alkuperäisten kehittäjien kirjoituksina. Saloviidan teos ei siis korvaa käsikirjaa yhteistoiminnallisen oppimisen keskeisenä teoksena. Uutena panoksena voi pitää yritystä avata menetelmiä tiukasti luokkahuonekontekstin näkökulmasta, sosiaalipsykologisen aineksen esiinnostamista oppimisen taustateoriana sekä yhteistoiminnallisen oppimisen tarkastelua perinteisen erityispedagogiikan korvaajana.

Kirjan otsikon termi osallistava kasvatus on englannin käsitteen inclusion käännös. Sillä viitataan sosiaalisesti erityiseksi tuotettujen ryhmien ja tavallisten ryhmien toimimiselle samassa tilassa. Juuri osallistavan kasvatuksen yhdistäminen yhteistoiminnalliseen oppimiseen on teoksen lupaavinta antia. Siksi onkin sääli, että tämä teema jää vähälle kehittelylle.

Sivumääräisesti osallistavaa kasvatusta käsitellään kahdeksan sivun verran. Sitä sivutaan muualla kirjassa. Se ei kuitenkaan tematisoidu keskeisissä osioissa. Luokkien valikointia esiteltäessä ei käsitellä yhteistoiminnallista oppimista, vaan oppilaiden opettamista samassa tilassa ylipäätään. Yhteistoiminnallisten menetelmien vaikutusta esittelevissä tutkimussa ei viitata erityispedagogiikkaan, vaan pysytään normaalissa kehyksessä. Voitaneen siis todeta, että Saloviidan teos avaa kentän yhteistoiminnallisista menetelmitä sekä erilaisuuden kohtaamisesta, mutta ei tyhjennä tämän kentän ainesta.

\section{Yhteistoiminnallisuuden vaih- toehtot}

Jos opetusmenetelmä on väline eikä päämäärä, olisi hyödyksi tuntea myös välineen kritiikkiä. Sama väline ei sovellu kaikkiin tilanteisiin. Menetelmän itsenäinen ja onnistunut käyttö edellyttää paitsi tietoa eduista myös siitä, mikä on menetelmän luonteva sovellusala. Opetusmenetelmäkirjallisuudelle tyypillisesti kirja ei auta vastaamaan tähän kysymykseen. Kirjassa ei tarjota jäsentynyttä yhteistoiminnallisen oppimisen kritiikkiä tai pohdintaa, milloin sitä ei kannata soveltaa. Saloviidan mukaansa menetelmästä on vaikea löytää kielteisiä puolia, jos sitä vertaa yksilölliseen opiskeluun.

Toisinaan Saloviita kirjoittaa ikään kuin perinteisen opetuksen vaihtoehtoina olisi vain ryhmätyö ja sen kehittynyt muoto, yhteistoiminnallinen oppiminen.
Muut tavat tuoda mukaan sosiaalista tiedon konstruointia ja kokemuksellisuutta jäävät mainitsematta. Koska teos keskittyy peruskoulun, on sen painopiste tiedollisen aineksen haltuunotossa. Näin muut pedagogiikat, kuten vaikkapa seikkailu- ja taidekasvatus jäävät tarkastelutta. Ne ehkä tukisivat Saloviidan ja laajemmin yhteistoiminnallisten oppimisen edustajien toivetta siitä, että koulun toimintakulttuuri on muutettavissa yhteisölliseksi ja erilaisuutta hyväksyväksi.

Saloviidan teos soveltunee parhaimmin sinne, mihin se epäilemättä on tarkoitettukin. Se pystyy osoittamaan peruskoulun opettajille, että opettajajohtoinen toimintamalli on mahdollista murtaa ja että yhteistoiminnalliset tavat tuovat mukanaan useita etuja. Muissa ympäristöissä toimiville teos toimii muistinvirkistäjänä ja näkökulmien herättäjänä.

\section{Tomi Kiilakoski}

Arvion kirjoittaja tekee Suomen Kulttuurirahaston apurahan turvin väitöskirjaansa aiheena kasvatus teknolosoituvassa kulttuurissa. 